\section{COTTON GROWING IN THE BRITISH EMPIRE.}

THE report to the Board of Trade of the Empire Cotton Growing Committee has just been issued (Cmd. 523 , price is. $6 d$. net). Briefly, the story there told may be summed up as follows: The British cotton mills have been directly adapted to utilise the American long-staple cottons, and they produce, in consequence, the high-class goods for which they are famed. The mills may, in fact, be described as unable to use up the abundant, though much shorter, staples of India and certain other countries of the British Empire. For some years past the mills of the States have begun to work up more and still more of their home supply (of superior cottons), so that the position has thus come about that Britain must be prepared, in the near future, to dispense with a large amount of the American raw cottons hitherto regarded as essential. In what way and how soon can this feat be accomplished? Delay may mean famine to the immense community (something like $5,000,000$ people) more or less dependent on the cotton mills of Lancashire.

The answer is presumed to have been given by the report before us. But the perusal of the volume leaves a somewhat confused impression, in which we seem to have been studying something closely resembling the meanderings of a great river which flows through the tropical and sub-tropical regions of the world. It engulfs many great tributaries, and is finally discharged into the ocean of British cotton manufacturing interests by six mouths or sub-committees. All this may be fine, and certainly is ingeniously elaborated, but when we read that it is intended to flow on for ever, we begin to wonder if a complex organisation of impersonal and mutable committees is likely to prove the most satisfactory course for obtaining the very-much-to-be-desired results.

The raising of funds (Imperial and Colonial, etc.); the organisation of existing resources; the institution of greater specialisation in the working up of available supplies; the establishment of improvements in handling, transporting, and marketing the raw staple; the prevention of the practices of adulteration and damping; and many other such subjects, are all dealt with in the report, but they do not seem to resolve themselves into the promulgation of a concrete scheme of increased and improved production. Nevertheless, we are assured that the British Empire can be made selfsupporting in this matter, though we are not told where or how this is to be accomplished. It must be confessed that the whole history of cotton improvement is most disheartening. We read, for example, of a great scheme having been floated, some seventy years ago, to raise in Manchester a sum of $20,000,000 l$. to be expended in India, during five years, in measures calculated to forward India as a cotton-producing country. Nothing came of that great conception, though spasmodically, after intervals of neglect (due to No. 2626 , VOL. IO4] increased American supply), Associations, Committees, and Commissions were formed, and each in its day aroused considerable interest, but all proved more or less futile. Meanwhile, two great new manufacturing centres gradually progressed into importance--namely, the United States of America and India-and now these have to be reckoned with in the future.

There are, however, in the present report two important schemes-the training of men, and the establishment of research. In both we think the contemplated methods of accomplishment are likely to prove unsatisfactory.

But let the Central Research Institution, proposed in the Committee's report, become a permanent department of expert officials (not a committee of voluntary workers), and have handed over to it a desired programme of work, then we think a definite step would be taken in the right direction. The members of that institute could be held responsible and judged by results. Their programme should be: Research, Education, and Cotton Production. House them, therefore, in a building large enough to have fully equipped laboratories for research, give them as complete a library as possible, and build them a museum and herbarium. But let there be no hair-splitting separations into research as distinct from information-no divided responsibilities. Who can be better qualified to make public the results or materials obtained than the experts concerned? Information cannot, and should not, be separated from research in the way proposed by the report.

One-half at least of all the subjects of research that have to be investigated can be undertaken better in Manchester than in Egypt--the report suggests Egypt. Establish in Manchester a College of Cotton-a Central Research Institution, as it has been called--where both experts and planters can be trained, in close and personal relationship with the great manufacturing interests. One such centre is quite sufficient, and far better than the proposed lectureships and readerships in half-a-dozen colleges or universities, where plant physiology, plant genetics, mycology, entomology, and the like might be taught. In the one, expert and practical men would be directly and immediately trained for cotton planting; in the other, general instructions would be given that might never mature into cotton planting at all. No risks of this kind should be run; general principles of education must never be allowed to take the place of specific training and definite results.

The Indian Committee insist on the need for more detailed botanical investigation of the existing kinds of cotton in most of the cotton-growing tracts. . . . They consider selection as the first step in evolving better types, to be followed by plant-breeding, which, however, should be entrusted to selected officers who can devote personal attention and considerable time to it.

These passages we single out of the report because they denote acceptance of a most important issue. It has far too long been the habit of cotton experts to hold systematic studies up to 
ridicule. They have imagined that they were operating on certain species, or they have coined quasi-scientific names for equally illusory forms known to themselves but to no one else. There can be no manner of doubt that not only critical, but also even hypercritical, studies of all the species of Gossypium are imperatively necessary. The work accomplished in one country must be capable of immediate adoption in all others. This involves acceptance of definite specific standards throughout the Empire. No plot of land should, therefore, be cultivated with cotton, in the research experimental farms, without carefully prepared botanical samples being kept of the plant, of its seeds, and of its lint. These should be registered and preserved in both the herbarium and the museum, and, when found necessary, duplicates sent to all research stations, as also to the Central Research Institution. All further experiments could then contrast result after result, until definite progress had: been established or the plant rejected as worthless. We require the history of each species to be worked out in the herbarium, and its habitat thereby fully established, before it can be accepted as a unit for investigation.

Then, in collaboration with a fully equipped home institution, there should be opened out branch institutions in each of the more important centres of cotton cultivation within the British Empire. Results worked out in Egypt might be quite unsuited to India, to Africa, or to the West Indies. Each important centre must discover and establish its own stocks. After the students had passed through the home college, they would be sent out to the branch college of the locality for which they were being trained, and made to study there practical cotton planting, as well as learn the local aspects of the industry. They might with advantage be also sent, for a few months, to an American college.

So much for Research and Instruction; but it is next to useless to talk of "investigation" and "education" if no rational scheme can be submitted, side by side, of immediate and direct application. In India, for example, cotton is grown exclusively by natives, each of whom owns but a very few acres. It is believed that the Government is averse to granting land (at present cultivated by the people) to be handed over to Europeans. Tea planting became a European industry because it was organised in uncultivated waste lands. It might, therefore, be recommended to the Government of India to make every effort to organise cotton plantations on such conditions as were found possible. The planter, for example. might be guaranteed against loss while given all profits, but subject after, say, twenty or thirty years to being bought out. If some such scheme could be carried through, it is highly likely that in a very few years cotton planting would be established on a sound commercial basis, and then for a certainty be greedily taken over by the people themselves. Moreover, were it made known in India that a large cotton-growing scheme had been organised by the Government, landed proprietors NO. 2626 , VOL. IO47 might be expected to send their sons to England to be trained for running home-farms. Since India is the largest cotton-growing country within the Empire, success there would give the most immediate results; but what may be said of India is doubtless more or less true of most other cottongrowing centres.

It has, however, to be demonstrated that highclass cultivation will pay in order to overcome the peasant cultivation of to-day, with its impecuniosity that precludes advancement. The planters would all be trained pupils of the college, and given the advantages arranged for on condition of carrying out the principles enjoined on them and also of using the stock supplied from the local research station; but their plantations should on no account become experimental farms. The planters should, so far as possible, be free agents. The local research stations would no doubt require experimental farms on which to raise and develop seed, and these should be provided, but every effort should at the same time be put forth to organise a European cotton-planting industry, or at all events an industry on European lines. Indian experience (see the report of the Indian Cotton Committee ${ }^{1}$ ) would seem to establish at least one great practical conclusionnamely, that there are certain very restricted areas within which the so-called long staples of India can be produced immediately. Assuming that to be correct, cotton planting on a large scale should be at once organised within these tracts as the initial step.

In America success may be described as having been due to three main causes: (a) There were no vested interests of native cultivators to contend against; $(b)$ the cultivation was undertaken by Europeans who were mostly intelligent farmers; and $(c)$ the planters finally rejected the imported stocks, brought from India and the Levant, and evolved purely American stocks. It was these American stocks that gave the world most of the prized fine long staples. The lesson to be learnt is that the three directions indicated should be kept clearly in mind through all future endeavours. We may not be able at once to disregard local vested interests, but we can take the most promising course of ultimately overcoming them-for many years to come, planting must be on European lines if success is to be attained; and finally we must evolve in each centre its own stocks from purely indigenous, or at least long-acclimatised, plants.

Disregard of the vested interests of the people is more dangerous than ignorance of the requirements of the plant. As the Indian Committee says (and very properly), the cultivator's interests are paramount. It is on that account sailing very much too near the wind to speak, as in the report, of "control of seed" and "compulsory measures against cotton pests." No one, of course, could doubt the value of the arguments set forth in these paragraphs, but in certain countries they are highly impracticable. They

1 Report of the Indian Cotton Committee. (Published by Superintendent of Government of India Printing, rgrg.) Price $2 s$. 
could be applied in all Government farms and plantations, but what of the many millions of acres outside? No doubt it would be the most obvious solution of many pests to have a season, like the frost of winter in the United States and in the northern tracts of India, that would kill the cotton plant and the pests as well, so that next year's sowings would stand a chance of being clean. But in many parts of the cotton area of India two cotton crops are taken off the fields every yearthe uppam and nadam of Madras, for example. Cotton may, in fact, be seen growing throughout the year in almost any province of India, one crop coming immediately after the other. The soil is often such that a good staple may be raised on one plot of land, and an inferior on another closely adjacent, and the seasons of their production often overlap. Obviously, while there could not be any compulsory orders that would deprive the individual of his rights, the persuasion of personal advantage, once established by the success of neighbouring large plantations, would in a few years secure all that could be desired.

The salvation of the position is thus the establishment of independent large cotton plantations, but the most serious difficulty is the discovery of the alternative crop or crops most convenient and profitable. It is not cotton growing only (like tea planting) that has to be faced, but systematic tropical agriculture with a full rotation of crops. This aspect of the problem the report has, of course, not dealt with, and has only general principles to offer.

The extension into new areas -more especially lands with rich soils that need only enhanced schemes of water supply to bring them into bearing -is most fascinating, but, as the Indian Committee points out, better results may be looked for from an increase in the average annual yield than from new areas. That view is certainly correct, and should be faced by some practical scheme, and not by a panorama of committees.

GEORGE WATT.

\section{INDUSTRIAL AND MEDICAL RADIOLOGY.}

THE extent to which radiology has widened its scope during recent years was strikingly brought out by the exhibition of radiographs held very opportunely by the Röntgen Society at the Royal Photographic Society's galleries during January and February.

Radiology has usually been regarded as a special province of the physician and surgeon, which provides them with a routine means of quick and exact diagnosis. But radiology is spreading its NO. 2626 , VOL. IO4] wings into branches of activity far removed from medical endeavour, and the widening of its physical scope cannot fail to react beneticially on the older branch of the subject.

Simultaneously comes the awakening of the medical faculty generally to the importance and promise of physical methods and physical agencies as a means of progress in medical research. There is little doubt that within a short time every large and progressive hospital will have a physicist of standing on its staff; and in this connection we would congratulate the Middlesex Hospital on the good fortune which cnables it to establish what we believe is the first medical chair of physics in this country.

In particular, as regards radiology, the physicist will find work to hand in nearly every branch with which he comes in contact. Again, nearly all the

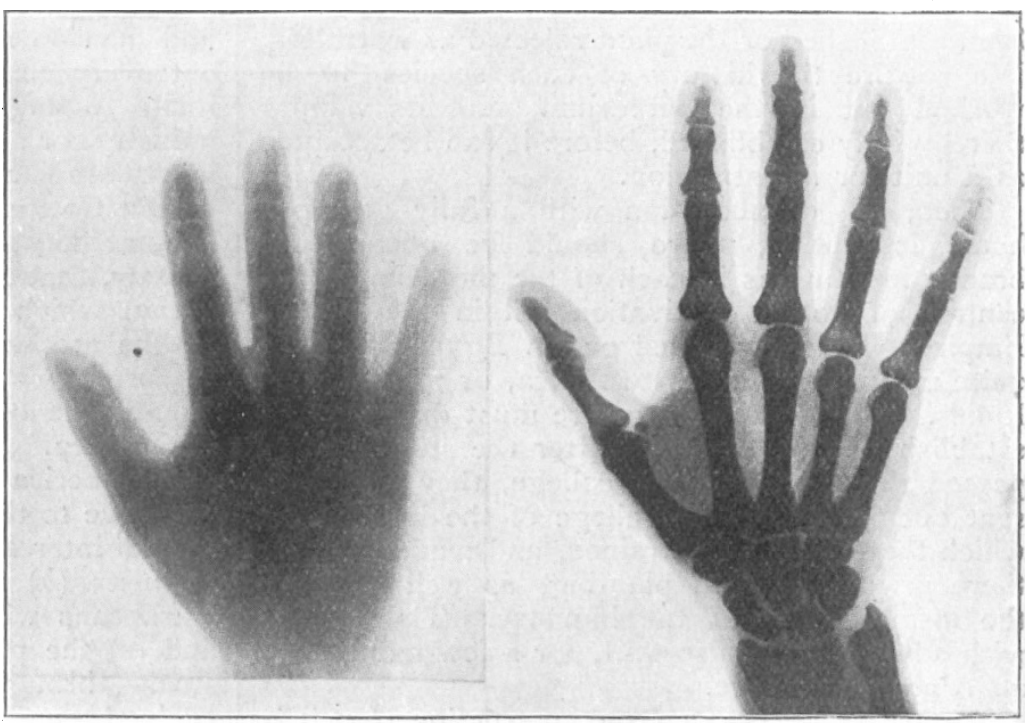

(a)

(b)

(Campbell Swinton.) problems of equipment and design are physical in character, and need physicists to tackle them, as America has already discovered to her profit. If the physicist can further obtain the co-operation of the electrical engineer, all-round improvements should speedily follow.

What of progress to date? The exhibition referred to here, although confined to radiographic prints, could very fairly be regarded as representative of present-day radiography, and as such it received generous approval from both the public and the Press. Some 200 prints were hung representing work by about thirty of the leading workers.

As a radiographer rarely takes his work beyond the negative stage, for the good reason that a print shows him no more, but usually rather less, than the negative, it was gratifying to find so high a pitch of photographic technique in the majority of the exhibits. On the other hand, few exhibitors had devoted much care or thought to the mounting 